\title{
PENGARUH PEMBERIAN EKSTRAK BUAH NAGA MERAH (Hylocereus polyrhizus) TERHADAP GAMBARAN SPERMATOGENESIS TIKUS PUTIH (Rattus norvegicus) GALUR WISTAR YANG DIINDUKSI PAKAN TINGGI LEMAK
}

\author{
Yara Cantika ${ }^{1}$, Cut Fauziah ${ }^{2}$, Yuni Setyaningsih ${ }^{3}$ \\ ${ }^{1,2,3}$ Fakultas Kedokteran Universitas Pembangunan Nasional Veteran Jakarta, Indonesia \\ E-mail: yaracantika95@gmail.com
}

\begin{abstract}
ABSTRAK
Spermatogenesis dipengaruhi oleh stres oksidatif yang dihasilkan dari peningkatan adipokin pro-inflamasi karena pola makan tinggi lemak. Namun, kerusakan sel-sel spermatogenesis diharapkan dapat dicegah dengan alternatif alami yaitu buah naga merah (Hylocereus polyrhizus). Penelitian bertujuan untuk menganalisa pengaruh pemberian ekstrak Hylocereus polyrhizus terhadap sel-sel spermatogenesis yang diinduksi pakan tinggi lemak. Penelitian berupa true-experiment. 30 ekor tikus dibagi ke dalam 5 kelompok. Kelompok 1 sampai 4 diberikan perlakuan selama 52 hari dan kelompok 5 selama 104 hari. Kelompok 1 kontrol negatif (K1) diberikan pakan standar, kelompok 2 Kontrol positif (K2) diberikan telur puyuh 10ml/kgBB, kelompok 3 Perlakuan 1 (P1) diberikan telur puyuh $10 \mathrm{ml} / \mathrm{kgBB}$ dan simvastatin $0,72 \mathrm{mg} /$ hari, kelompok 4 Perlakuan 2 (P2) diberikan telur puyuh $10 \mathrm{ml} / \mathrm{kgBB}$ dan ekstrak Hylocereus polyrhizus dosis $60 \mathrm{mg} /$ hari selama 52 hari, dan kelompok 5 Perlakuan 3 (P3) diberikan telur puyuh 10ml/kgBB dan ekstrak Hylocereus polyrhizus dosis 60mg/hari selama 104 hari. Analisis data menggunakan uji One Way ANOVA dilanjutkan uji (P-value=0,05) pada perlakuan 52 hari. Kelompok P1 dan P2 memperlihatkan perbaikan dan peningkatan spermatosit dan spermatid bermakna (p.000<0,05) dibandingkan kelompok K2. Kelompok P2 memiliki rata-rata sel spermatosit dan spermatid lebih tinggi dibandingkan kelompok P1 (p.000<0,05). Kelompok P2 52 hari sebanding dengan kelompok P3 104 hari (p.469>0,05) pada sel spermatid. Ekstrak Hylocereus polyrhizus selain memiliki mekanisme kerja seperti simvastatin juga memiliki kandungan antioksidan dan perlakuan jangka panjang tidak memberikan pengaruh buruk terhadap sel spermatogenesis. Kesimpulannya, ekstrak Hylocereus polyrhizus dosis 60mg/hari dapat memperbaiki dan meningkatkan sel-sel spermatogenesis yang diinduksi pakan tinggi lemak.
\end{abstract}

Kata Kunci : Hylocereus polyrhizus, pakan tinggi lemak, spermatogenesis, kolesterol, simvastatin

\begin{abstract}
Spermatogenesis can be affected by oxidative stress produced by the increasing of pro-inflammatory adipokines because of high fat diet. The spermatogenesis cells damaged can be prevented with natural substance such as red pitaya (Hylocereus polyrhizus). This study aims to analyze effect of Hylocereus polyrhizus extract on rat's spermatogenesis cells number that induced by high fat diet. This study had used true-experiment design. 30 rats were divided into 5 groups. Groups 1 to 4 had done treatment for 52 days and group 5 treatment for 104 days. Group 1 Negative control (K1) administered with standard diet, group 2 Positive control (K2) had administered quail egg $10 \mathrm{ml} / \mathrm{KgBW}$, group 3 Experiment 1 (P1) had administered quail egg polyrhyzus $10 \mathrm{ml} / \mathrm{Kg} \mathrm{BW}$ and with simvastatin 0,72mg/day, group 4 Experiment $2(\mathrm{P} 2)$ had administered quail egg $10 \mathrm{ml} / \mathrm{KgBW}$ and wth Hylocereus polyrhizus extract 60mg/day in 52 days, and group 5 Experiment $3(\mathrm{P} 3)$ had administered quail egg $10 \mathrm{ml} / \mathrm{KgBW}$ and with Hylocereus polyrhizus extract $60 \mathrm{mg}$ /day in 104 days. Data were analyzed by One Way ANOVA and continued with Post Hoc Tukey's HSD (P-Value=0,05) for 52 day groups. Group P1 and P2 showed repairing effect and increasing spermatocytes and spermatids (p.000<0,05) compared to group K2. Group P2 had more spermatids and spermatocytes than group P1 (p.000<0,05). Group P2 52 days' spermatid cells equalled to group P3 104 days (p.469>0,05). Hylocereus polyrhizus extract not only had mechanism like simvastatin but also contained antioxidant, and a long-term treatment had not proven bad effect to spermatogenesis cells. Conclusion. Hylocereus polyrhizus extract $60 \mathrm{mg} /$ day can repair and increase spermatogenesis cells induced with high fat diet.
\end{abstract}

Keywords : Hylocereus polyrhizus, high fat diet, spermatogenesis, cholesterol, simvastatin 


\section{PENDAHULUAN}

Gaya hidup memiliki dampak jangka panjang terhadap kesehatan seseorang. Gaya hidup sehat memiliki lima komponen yaitu perilaku tidak merokok, aktivitas fisik 30 menit setiap hari, berat badan ideal, pola makan ideal, dan konsumsi alkohol yang tidak berlebihan. Gaya hidup yang tidak sehat dengan pola makan tinggi lemak akan meningkatkan nilai kolesterol darah. ${ }^{1}$ Kadar kolesterol yang tinggi pada jangka waktu yang lama dapat mempengaruhi berbagai sistem organ, salah satu sistem organ yang paling sering terkena dampak adalah kardiovaskular yang akan bermanifestasi sebagai angina, serangan jantung dan stroke iskemik. ${ }^{2}$

Indonesia merupakan negara dengan konsumsi saturated fatty acids (SFA) tertinggi sebesar 20,9\%.3 Sebanyak 40,7\% warga Indonesia mengkonsumsi makanan tinggi lemak dengan angka mencapai 47,8\% dari penduduk DKI Jakarta. Hasil riset juga menunjukkan bahwa prevalensi konsentrasi kolesterol total lebih dari 200 $\mathrm{mg} / \mathrm{dL}$ adalah sebesar $35,9 \%$ pada populasi penduduk usia $\geq 15$ tahun. $^{4}$

Peningkatan kadar kolesterol total yang disebabkan olah konsumsi makanan tinggi lemak dapat mempengaruhi sel germinativum testis. Sel-sel adiposit menghasilkan adipokin pro-inflamasi yang akan menghasilkan Reactive Oxygen Species (ROS), inducible nitric oxide synthase (iNOS), dan Lipid Peroksidase (LPO). ${ }^{5,6}$ Sementara faktor-faktor antioksidan seperti Superoxide Dismutase (SOD), Gluthatione Peroxidase (GPx), dan Catalase tidak dapat menanggulangi jumlah radikal bebas sehingga hal-hal tersebut akan menyebabkan kerusakan selsel testis dengan cara merangsang perusakan DNA, membran sel, dan apoptosis. ${ }^{7,8}$ Stres oksidatif yang dihasilkan oleh konsumsi makanan tinggi lemak juga akan menekan kadar testosteron, perubahan rasio testosteron dengan estradiol, dan penurunan Follicle-Stimulating hormone (FSH) sehingga hormon-hormon bersifat protektif terhadap sel germinativum berkurang. ${ }^{9,10}$ Hal-hal tersebut akan menyebabkan penurunan jumlah sel-sel spermatogenesis yang dapat dinilai secara kuantitatif. ${ }^{11}$

Jumlah sel-sel spermatogenesis yang menurun akibat peningkatan kadar kolesterol dapat diatasi dengan penggunaan statin karena dilaporkan sebelumnya penggunaan antioksidan dan penggunaan obat golongan statin memperlihatkan sifat proteksi pada testis dan fungsi reproduksi pada keadaan tinggi kadar kolesterol darah, bahkan meningkatkan parameter semen dan memperbaiki disfungsi endokrin gonad. ${ }^{9}$ Obat golongan statin bekerja dengan cara menginhibisi HMG-CoA reduktase sehingga dapat menurunkan kolesterol. ${ }^{12}$ Namun, Sekitar 10\%-15\% pasien dapat mengalami intoleransi statin. Manifestasi dari intoleransi obat ini seperti miopati dan hepatotoksisitas sehingga pemakaian obat harus dibawah pengawasan medis. 13 Maka, dibutuhkan alternatif alami untuk dikonsumsi sehari-hari seperti tanaman herbal maupun buah-buahan yang diharapkan dapat mengontrol kadar kolesterol dan memiliki efek samping yang lebih rendah. ${ }^{14}$

Sebagai negara tropis, Indonesia memiliki potensi budidaya beraneka ragam tanaman. Salah satu hasil dari tanaman yang mulai banyak dikonsumsi adalah buah naga (Hylocereus sp.) karena diyakini memiliki kandungan kimia yang bermanfaat bagi kesehatan. ${ }^{15}$ Buah naga merah (Hylocereus polyrhizus) merupakan jenis buah naga yang sudah banyak dikonsumsi masyarakat Indonesia. ${ }^{16}$

Buah naga merah memiliki total dietary fiber (TDF) cukup tinggi, aktivitas antioksidan yang baik sebesar 67,45 ppm, dan Oxygen radical absorbance capacity (ORAC) sebesar 7,6 $\mu \mathrm{M}$ TE/g puree kandungan ini lebih banyak dari buah tropis lainnya seperti buah naga putih, leci, sawo, mangga, lengkeng, dan sebagainya. ${ }^{17,18}$ Buah naga merah juga mengandung zat 
yang bekerja seperti statin yaitu saponin dan triterpenoid. ${ }^{19}$

Penelitian sebelumnya di Indonesia pada tikus terbukti bahwa buah naga merah dosis $60 \mathrm{mg} /$ hari dapat memperbaiki profil lipid. ${ }^{14}$ Buah naga merah dosis $120 \mathrm{mg} /$ hari memiliki efektivitas yang sama dengan obat golongan statin dosis $10 \mathrm{mg} / \mathrm{hari}$ dalam menurunkan kolesterol. ${ }^{20}$ Lalu, buah naga merah dosis $250 \mathrm{mg} / \mathrm{Kg} / \mathrm{hari}$ dan 500 $\mathrm{mg} / \mathrm{Kg} /$ hari terbukti dapat meningkatkan proses spermatogenesis tikus selama tidak mencapai dosis letal $1000 \mathrm{mg} / \mathrm{Kg} / \mathrm{hari}$, namun hasil ini didapatkan tanpa melakukan induksi pakan tinggi lemak selama 25 hari. $^{21}$

Berdasarkan uraian di atas maka peneliti tertarik melakukan penelitian untuk menganalisa pengaruh pemberian ekstrak buah naga merah dalam mencegah penurunan jumlah sel-sel spermatogenesis yang disebabkan oleh konsumsi makanan tinggi lemak, berkaitan dengan strategi preventif terhadap dampak konsumsi makanan tinggi lemak. Hal ini sesuai pasal 12 kewajiban umum dokter menurut kode etik kedokteran 2012 bahwa seorang dokter wajib memperhatikan aspek pelayanan kesehatan meliputi bidang promotif, preventif, kuratif, rehabilitatif, dan paliatif.

\section{METODE PENELITIAN}

\section{Desain Penelitian}

Penelitian ini menggunakan desain penelitian true-experiment dengan rancangan penelitian posttest-only controlgroup design. Desain ini mengendalikan efek perancu dari pretest. ${ }^{22}$ Populasi secara randomisasi sederhana (simple randomization ${ }^{23}$ Dikelompokkan, perlakuan diberikan pada kelompok eksperimen dan semua kelompok diukur dengan cara posttest. ${ }^{22}$

Hasil penelitian dari kelima kelompok didapatkan berupa hasil posttest jumlah parameter spermatogenesis. Perlakuan selama satu siklus spermatogenesis akan dianalisa melalui uji
ANOVA One Way $(\mathrm{P}$ value $=0,05)$. ANOVA One Way adalah suatu uji statistik untuk melihat perbedaan rata-rata antar beberapa kelompok hanya dalam satu kali pengukuran. Asumsi yang harus dipenuhi pada uji ini adalah jenis data yang dihubungkan numerik dengan katagorik, data terdistribusi normal, dan homogen. ${ }^{24}$ Setelah itu dilakukan uji Post Hoc Tukey's HSD (Honestly Significant difference) untuk melihat kelompok mana saja yang memilik beda rata-rata yang bermakna. ${ }^{25}$ Apabila asumsi tidak terpenuhi maka dapat dilakukan uji alternatif non-parametrik Kruskal-Wallis. ${ }^{26}$ Sementara uji analisis antara kelompok ekstrak buah naga merah selama 52 hari dengan 104 hari menggunakan T-test Independent karena hanya membandingkan dua kelompok katagorik. Apabila data tidak terdistribusi normal dilakukan uji non-parametrik Mann-Whitney $U .{ }^{27}$

\section{Populasi dan Sampel}

Penelitian ini menggunakan sampel tikus putih (Rattus norvegicus) galur wistar, jantan, usia \pm 8 minggu, dan berat $\pm 200-250$ gram.

Dalam penelitian ini tikus akan dibagi ke dalam 5 kelompok yang terdiri dari satu kelompok kontrol negatif, satu kelompok kontrol positif, dan tiga kelompok eksperimental. Kelompok 1 kontrol negatif (K1) diberikan pakan standar, kelompok 2 kontrol positif (K2) diberikan pakan tinggi lemak, kelompok 3 perlakuan 1 (P1) diinduksi pakan tinggi lemak lalu diintervensi dengan Simvastatin dosis $0,72 \mathrm{mg} / \mathrm{KgBB}$, dan kelompok 4 perlakuan 2 (P2) diinduksi pakan tinggi lemak lalu diintervensi dengan ekstrak buah naga merah dosis 60mg/hari. Kelompok 1 sampai 4 dilakukan selama 52 hari atau satu siklus spermatogenesis. Kelompok 5 diinduksi pakan tinggi lemak lalu diintervensi dengan ekstrak buah naga merah selama 104 hari atau dua siklus spermatogenesis. 
Kriteria inklusi penelitian ini adalah tikus putih (Rattus norvegicus) jantan galur Wistar, dewasa (usia 8 minggu), berat badan 200-250 gram, kondisi sehat (bergerak aktif dan tidak cacat).

\section{Pengambilan Sampel}

Sampel diambil menggunakan teknik randomisasi sederhana (simple randomization) dengan cara penarikan nomor undian. Teknik randomisasi akan mengurangi bias seleksi dan perancu dengan terbaginya secara seimbang variabel-variabel yang tidak diteliti. ${ }^{28}$

\section{Prosedur Penelitian}

Penelitian eksperimental ini meliputi tahap persiapan alat dan bahan, persiapan tikus, dan prosedur pelakuan pada tikus mulai dari aklimatisasi sampai dengan pembedahan tikus. Setelah pembedahan, organ testis dibuat menjadi preparat dengan melakukan pewarnaan selanjutnya diperiksa secara mikroskopik dengan perbesaran 400X sebanyak 5 lapang pandang per preparat, dalam satu lapang pandang terdapat satu tubulus seminiferus utuh. Setelah didapatkan hasil data, dilakukan uji statistik.

\section{HASIL DAN PEMBAHASAN}

\section{Hasil}

Pada penelitian ini dilakukan induksi pakan tinggi lemak dengan menggunakan telur puyuh dosis $10 \mathrm{ml} / \mathrm{KgBB}$ lalu diberikan perlakuan berupa simvastatin dosis $0,72 \mathrm{mg} /$ hari dan Ekstrak buah naga merah dosis $60 \mathrm{mg} /$ hari dalam satu siklus dan dua siklus spermatogenesis. Berikut hasil rata-rata kadar kolesterol total tiap kelompok perlakuan.
Tabel 1. Rata-rata Kadar Kolesterol

\begin{tabular}{lc}
\hline \multicolumn{1}{c}{ Perlakuan } & $\begin{array}{c}\text { Rata-rata Kadar } \\
\text { Kolesterol } \pm \text { SD }\end{array}$ \\
\hline Kontrol Negatif & $64,83 \pm 10,19$ \\
Kontrol Positif & $101,17 \pm 6,34$ \\
Simvastatin & $73,17 \pm 9,81$ \\
Naga Merah 52 & $54,17 \pm 2,32$ \\
Naga Merah 104 & $71,17 \pm 22,59$ \\
\hline
\end{tabular}

Berdasarkan penelitian sebelumnya yang menggunakan pakan standar Bravo512 nilai rujukan kadar kolesterol puasanya adalah dibawah $89 \mathrm{mg} / \mathrm{dl} .{ }^{29}$ Dari hasil ratarata kadar kolesterol penelitian ini, pada kelompok kontrol negatif didapatkan angka $64,83 \pm 10,19 \mathrm{mg} / \mathrm{dl}$ yang merupakan kadar kolesterol total normal pada penelitian ini. Sementara, kadar kolesterol tertinggi terdapat pada kelompok kontrol positif memiliki kadar kolesterol total sebesar $101,17 \pm 6,34 \mathrm{mg} / \mathrm{dl}$, hal ini menunjukkan bahwa induksi pakan tinggi lemak menggunakan telur puyuh dosis 10 $\mathrm{ml} / \mathrm{kgBB}$ dapat meningkatkan kadar kolesterol total darah.

Kelompok perlakuan menggunakan simvastatin dan ekstrak buah naga merah didapatkan hasil berturut-turut sebesar $73,17 \pm 9,81 \mathrm{mg} / \mathrm{dl}$ dan $54,17 \pm 2,32 \mathrm{mg} / \mathrm{dl}$ menunjukkan bahwa pemberian simvastatin dan ekstrak buah naga merah selama satu siklus spermatogenesis memiliki kadar kolesterol lebih rendah dibandingkan dengan kontrol positif yang diinduksi pakan tinggi lemak dan tidak diberikan intervensi.

Pemberian ekstrak buah naga antara satu siklus spermatogenesis dengan dua siklus spermatogenesis didapatkan hasil berturut-turut $54,17 \pm 2,32 \mathrm{mg} / \mathrm{dl}$, dan $71,17 \pm 22,59$. Hasil ini memperlihatkan peningkatan kadar kolesterol.

Sesuai dengan tujuan penelitian ini yaitu menganalisa pengaruh pemberian ekstrak buah naga merah (Hylocereus polyrhizus) terhadap gambaran spermatogenesis testis tikus putih (Rattus norvegicus) yang diinduksi pakan tinggi lemak. Berikut disajikan hasil rata-rata sel spermatogenesis tiap kelompok perlakuan. 
Tabel 2. Rata-rata Sel Spermatogenesis

\begin{tabular}{|c|c|}
\hline Perlakuan & $\begin{array}{c}\text { Rata-rata Kadar } \\
\text { Kolesterol } \pm \text { SD }\end{array}$ \\
\hline \multicolumn{2}{|l|}{ Spermatogonium } \\
\hline Kontrol Negatif & $49,27 \pm 5,06$ \\
\hline Kontrol Positif & $45,83 \pm 8,69$ \\
\hline Simvastatin & $46,43 \pm 5,23$ \\
\hline Naga Merah 52 & $49,87 \pm 4,77$ \\
\hline Naga Merah 104 & $55,77 \pm 9,02$ \\
\hline \multicolumn{2}{|l|}{ Spermatosit } \\
\hline Kontrol Negatif & $69,87 \pm 6,57$ \\
\hline Kontrol Positif & $157,47 \pm 17,01$ \\
\hline Simvastatin & $66,73 \pm 7,15$ \\
\hline Naga Merah 52 & $112,63 \pm 9,45$ \\
\hline Naga Merah 104 & $129,07 \pm 9,34$ \\
\hline \multicolumn{2}{|l|}{ Spermatid } \\
\hline Kontrol Negatif & $158,60 \pm 17,18$ \\
\hline Kontrol Positif & $48,03 \pm 8,67$ \\
\hline Simvastatin & $165,83 \pm 25,04$ \\
\hline Naga Merah 52 & $205,37 \pm 33,56$ \\
\hline Naga Merah 104 & $217,77 \pm 22,40$ \\
\hline \multicolumn{2}{|l|}{ Sertoli } \\
\hline Kontrol Negatif & $11,37 \pm 1,19$ \\
\hline Kontrol Positif & $10,97 \pm 1,86$ \\
\hline Simvastatin & $12,27 \pm 1,18$ \\
\hline Naga Merah 52 & $12,30 \pm 1,03$ \\
\hline Naga Merah 104 & $12,33 \pm 0,98$ \\
\hline Tabel & secara \\
\hline
\end{tabular}

menunjukkan pada sel spermatogonium dan sel sertoli didapatkan hasil rata-rata yang tidak terlalu jauh. Namun, Pada sel spermatosit dan sel spermatid terdapat variasi rata-rata yang sangat berbeda.

Kelompok sel spermatosit memperlihatkan peningkatan jumlah sel terbesar pada perlakuan kontrol positif dengan rata-rata $157,47 \pm 17,01$. Angka ini sangat jauh dari rata-rata sel kontrol negatif sebesar $\quad 69,87 \pm 6,57$. Penggunaan Simvastatin memberikan kadar rata-rata yang mirip dengan kontrol negatif yaitu $66,73 \pm 7,15$. Sementara, pemberian ekstrak buah naga merah 52 dan 104 hari menggambarkan peningkatan jumlah sel yang cukup besar dengan rata-rata $112,63 \pm 9,45$ dan $129,07 \pm 9,34$.

Hasil sel spermatid menunjukkan bahwa rata-rata sel kontrol positif mengalami penurunan dengan angka 48,03 $\pm 8,67$ dibandingkan dengan kontrol negatif yang sebesar $158,60 \pm 17,18$ hal ini menggambarkan bahwa pakan tinggi lemak menurunkan jumlah sel spermatid.
Sementara penggunaan simvastatin dapat meningkatkan jumlah sel spermatid dengan rata-rata $165,83 \pm 25,04$ mendekati angka normal kontrol negatif penelitan. Pemberian ekstrak buah naga merah selama 52 dan 104 hari dapat meningkatkan jumlah sel spermatid berturut-turut sebesar $205,37 \pm 33,56$ dan $217,77 \pm 22,40$.

\section{Pembahasan}

Penelitian ini bertujuan untuk menganalisa pengaruh pemberian ekstrak buah naga merah (Hylocereus polyrhizus) terhadap gambaran spermatogenesis testis tikus putih (Rattus norvegicus) yang diinduksi pakan tinggi lemak.

Hasil penelitian diambil setelah perlakuan selama 52 hari dan 104 hari. Data yang diambil berupa hasil pemeriksaan kadar kolesterol dan perhitungan jumlah sel spermatogenesis tikus pada tiap kelompok perlakuan. Tikus yang sudah mendapat perlakuan akan ditimbang, dipuasakan selama 10 jam, lalu dilakukan pengambilan darah dan pembedahan organ testis sehingga dapat dibuat menjadi preparat yang akan dihitung di bawah mikroskop cahaya dengan perbesaran 400x. Setiap satu preparat akan dilihat 5 lapang pandang, dalam 1 lapang pandang terdapat 1 tubulus seminiferus utuh. Puasa dilakukan untuk menghindari kerancuan hasil pemeriksaan karena konsumsi makanan terkahir tikus. Puasa 10-12 jam berfungsi untuk mengurang variabilitas substansi dalam darah yang akan diperiksa. ${ }^{30}$

Perlakuan ekstrak buah naga merah selama 52 hari dan 104 hari dilakukan untuk membandingkan pengaruh ekstrak buah naga merah dalam jangka waktu subkronis dan kronis selama satu siklus spermatogenesis dan dua siklus spermatogenesis. Uji pengaruh suatu ekstrak dapat dibagi menjadi 4 jangka waktu yaitu akut, subakut, subkronis, dan kronis. Akut dilakukan selama 14 hari, subakut hingga 28 hari. ${ }^{31}$ Subkronis mulai sampai dengan 90 hari, dan kronis diatas 90 hari. $^{32}$ 


\section{Pembahasan Kadar Kolesterol}

Nilai signifikansi uji One Way ANOVA sebesar 000 (P-value < 0,05) pada kelompok kolesterol perlakuan selama 52 hari. Hasil ini melaporkan bahwa terdapat perbedaan rata-rata yang bermakna antara kelompok perlakuan. Lalu, untuk mengetahui kelompok mana yang memiliki perbedaan bermakna dilakukan uji post hoc Tukey's HSD.

Tabel 3. Perbandingan Kolesterol Perlakuan Selama 52 Hari

\begin{tabular}{lcc}
\hline \multicolumn{1}{c}{ Perlakuan } & Kolesterol & Sig. \\
\hline Kontrol Negatif & $64,83 \pm 10,19$ & .000 \\
Kontrol Positif & $101,17 \pm 6,34$ & \\
\hline Kontrol Positif & $101,17 \pm 6,34$ & .000 \\
Simvastatin & $73,17 \pm 9,81$ & \\
\hline Kontrol Positif & $101,17 \pm 6,34$ & .000 \\
Buah Naga Merah & $54,17 \pm 2,32$ & \\
\hline Simvastatin & $73,17 \pm 9,81$ & .002 \\
Buah Naga Merah & $54,17 \pm 2,32$ & \\
\hline
\end{tabular}

Setelah kontrol negatif dibandingkan dengan kontrol positif didapatkan signifikansi sebesar .000 (P-value $<0,05)$ maka terdapat perbedaan rata-rata yang bermakna sebesar 36,33. Berdasarkan signifikansi yang didapatkan dari olah data maka dapat disimpulkan bahwa pemberian telur puyuh dengan dosis $10 \mathrm{mg} /$ hari selama 52 hari lebih berpengaruh terhadap peningkatan kadar kolesterol tikus. Peningkatan yang terjadi dikarenakan tingginya asam lemak jenuh yang terkandung dalam kuning telur puyuh. Asam lemak ini akan mengalami proses metabolisme oksidasi beta dan menghasilkan asetil KoA yang merupakan prekursor dari kolesterol. ${ }^{33}$

Kedua kelompok yang dilakukan Intervensi dibandingkan dengan kontrol positif memperlihatkan nilai signifikansi .000 (P-value < 0,05), maka kedua perlakuan dapat menurunkan kadar kolesterol pada tikus yang diinduksi pakan tinggi lemak.

Simvastatin bekerja dengan menghambat kerja enzim HMG-KoA
Reduktase. $^{2}$ sehingga HMG-KoA tidak dapat direduksi menjadi mevalonat sehingga sintesis kolesterol tidak dapat berjalan. ${ }^{34}$ Maka terjadi penurunan kadar kolesterol dengan perbedaan rata-rata sebesar 28,00 pada kelompok eksperimen simvastatin.

Buah naga merah memiliki berbagai kandungan yang dapat menurunkan kadar kolesterol seperti alkaloid, saponin, antioksidan (fenol, flavonoid, asam askorbat, betasianin), triterpenoid, niasin, serat, dan asam lemak tidak jenuh, oleh karena itu buah naga merah dapat menurunkan kadar kolesterol dengan perbedaan rata-rata $47,00 .{ }^{19}$

Saponin dan Triterpenoid bekerja dengan menghambat HMG KoA reduktase. ${ }^{19,35}$ Senyawa fenol, betasianin, dan asam askorbat menetralkan radikal bebas dan radikal perioksida sehingga stres oksidatif menurun. ${ }^{19}$ Flavonoid secara langsung mendonorkan ion hidrogen untuk stabilisasi radikal bebas dan secara tidak langsung merangsang ekspresi gen antioksidan. Selain itu flavonoid meningkatkan ekskresi getah empedu sehingga mengurangi kadar kolesterol dalam tubuh. ${ }^{19,36}$

Jika pengaruh ekstrak buah naga merah dibandingkan dengan penggunaan obat pilihan golongan statin dalam menurunkan kadar kolesterol total, didapatkan signifikansi sebesar .002 (Pvalue $<0,05)$, maka pemberian buah naga merah lebih bermakna dalam menurunkan kadar kolesterol dibandingkan penggunaan simvastatin hal ini bertentangan dengan hasil penelitian sebelumnya yang dilakukan oleh Sharan 2017 yang menyatakan bahwa potensi statin dosis $10 \mathrm{mg} /$ hari selama 28 hari lebih kuat dibandingkan ekstrak buah naga merah dengan dosis $120 \mathrm{mg} /$ hari dalam menurunkan kadar kolesterol. Hal ini dapat terjadi karena dalam penelitian ini dilakukan pemberian ekstrak lebih lama yaitu selama 52 hari dan penelitian ini melakukan induksi pakan tinggi lemak dan intervensi ekstrak buah naga merah secara bersamaan, sehingga hanya dapat menguji 
efektivitas buah naga merah sebagai strategi preventif dalam menghindari kenaikan kadar kolesterol darah. Buah naga merah memiliki kandungan yang bekerja seperti simvastatin yaitu Saponin dan Triterpenoid yang dapat mendegradasi dan menghambat kerja enzim HMG KoA Reduktase sehingga dapat menurunkan kadar kolesterol darah tikus putih. ${ }^{19,24}$

Tabel 4. Perbandingan Kolesterol Perlakuan Buah Naga Merah 52 hari dengan 104 hari

\begin{tabular}{lcc}
\hline \multicolumn{1}{c}{ Perlakuan } & Kolesterol & Sig. \\
\hline 52 Hari & $54,17 \pm 2,32$ & .015 \\
104 Hari & $71,17 \pm 22,59$ & \\
\hline
\end{tabular}

Kadar kolesterol pada kelompok perlakuan pemberian ekstrak buah naga merah selama 52 hari dan 104 dengan menggunakan uji Mann-Whitney $U$ menunjukkan angka signifikansi .015 (Pvalue $<0,05)$. Hal ini menunjukkan adanya penurunan efektivitas ekstrak buah naga merah dalam mengontrol kadar kolesterol setelah pemberian selama 104 hari. Dalam penelitian ini, tidak ada kematian pada kelompok tikus yang diberikan ekstrak secara kronis. Penelitian sebelumnya yang meneliti tentang efek toksik ekstrak buah naga merah pada pemberian akut (14 hari) dan subkronis (28 hari) menyatakan bahwa pemberian ekstrak buah naga merah dengan interval dosis $250 \mathrm{mg} / \mathrm{hari}, 500 \mathrm{mg} / \mathrm{hari}$, dan $1000 \mathrm{mg} /$ hari relatif aman diberikan secara per oral. Selama pemberian dosis tidak melewati dosis letal yaitu melebihi 1000 $\mathrm{mg} /$ hari. ${ }^{28}$ Maka, pemberian buah naga merah masih efektif dalam mengontrol kadar kolesterol dan tidak bersifat toksik.

\section{Pembahasan Sel-sel Spermatogenesis}

Pada penelitian ini terlihat peningkatan jumlah sel-sel spermatosit dan penurunan jumlah sel spermatid pada kontrol positif dibandingkan kontrol negatif seperti gambar 20. Perbandingan kelompok kontrol positif dengan kelompok eksperimen simvastatin dan pemberian ekstrak buah naga merah selama satu siklus spermatogenesis, memperlihatkan perbaikan diferensiasi sel spermatosit menjadi spermatid berdasarkan peningkatan jumlah sel-sel spermatid. Kemampuan ekstrak buah naga merah dibandingkan pemberian simvastatin terlihat lebih baik ditandai dengan peningkatan jumlah sel spermatosit dan spermatid yang terlihat pada gambar. Pada pemberian kronis selama dua kali siklus spermatogenesis terlihat jumlah sel-sel tidak mengalami penurunan jika dibandingkan dengan pemberian ekstrak buah naga merah selama satu siklus spermatogenesis. Untuk mengetahui kebenarannya secara kuantitatif dilakukan penghitungan jumlah sel-sel spermatogenesis yang akan diuji menggunakan ANOVA One Way.

Analisa statistik jumlah sel-sel spermatogenesis mendapatkan hasil uji One Way ANOVA untuk sel spermatogonium sebesar .597 dan sertoli .259 (P-value > 0,05), maka dapat disimpulkan bahwa tidak ada perbedaan rata-rata yang bermakna pada jenis sel tersebut.

Pakan tinggi lemak dan pemberian intervensi tidak mempengaruhi jumlah spermatogonium seperti yang ditampilkan dari hasil uji statistik. Sel spermatogonium membelah secara mitosis untuk memperbarui jumlah spermatogonium stem sel, spermagonium proliferatif, dan memproduksi spermatogonium diferensiasi. ${ }^{37}$ Pembelahan Mitosis hanya menghasilkan dua anak sel yang memiliki gen identik dengan sel sebelumnya. ${ }^{38}$ Sehingga jumlah spermatogonium cenderung tidak berubah.

Sel sertoli tidak mendapatkan pengaruh atas perlakuan. Hal ini karena nutrisi tidak berpengaruh terhadap jumlah sertoli pada tubulus seminiferus dibuktikan dengan penelitian yang menginduksi keadaan defisiensi nutrisi, hasilnya sel sertoli tidak mengalami abnormalitas maupun terpengaruh karena kurangnya vitamin. Hal ini membuktikan bahwa 
resistensi sel sertoli terhadap keadaan nutrisi lebih baik dibandingkan sel germinal. ${ }^{39}$ Penelitian lainnya menyatakan bahwa keadaan nutrisi mempengaruhi kemampuan fungsional sel sertoli, namun tidak ada perubahan terhadap jumlah sertoli antara diet standar, diet tinggi nutrisi, dan diet rendah nutrisi. ${ }^{4}$

Sel spermatosit dan sel spermatid dalam uji ANOVA One Way menghasilkan signifikansi sebesar .000 (P-Value < 0,05). Berdasarkan hal tersebut, dapat disimpulkan bahwa terdapat perbedaan rata-rata antara kelompok perlakuan. Untuk melihat kemaknaan dilakukan Uji post hoc Tukey's HSD.

Tabel 5. Perbandingan Rata-rata Sel Spermatosit Perlakuan Selama 52 Hari

\begin{tabular}{lcc}
\hline \multicolumn{1}{c}{ Perlakuan } & Rata-rata & Sig. \\
\hline Kontrol Negatif & $69,87 \pm 6,57$ & .000 \\
Kontrol Positif & $157,47 \pm 17,01$ & \\
\hline Kontrol Positif & $157,47 \pm 17,01$ & .000 \\
Simvastatin & $66,73 \pm 7,15$ & \\
\hline Kontrol Positif & $157,47 \pm 17,01$ & .000 \\
Buah Naga Merah & $112,63 \pm 9,45$ & \\
\hline Simvastatin & $66,73 \pm 7,15$ & .000 \\
Buah Naga Merah & $112,63 \pm 9,45$ & \\
\hline
\end{tabular}

Tabel 6. Perbandingan Rata-rata Sel Spermatid Perlakuan Selama 52 Hari

\begin{tabular}{lcc}
\multicolumn{1}{c}{ Perlakuan } & Rata-rata & Sig. \\
\hline Kontrol Negatif & $158,60 \pm 17,18$ & .000 \\
Kontrol Positif & $48,03 \pm 8,67$ & \\
\hline Kontrol Positif & $48,03 \pm 8,67$ & .000 \\
Simvastatin & $165,83 \pm 25,04$ & \\
\hline Kontrol Positif & $48,03 \pm 8,67$ & .000 \\
Buah Naga Merah & $205,37 \pm 33,56$ & \\
\hline Simvastatin & $165,83 \pm 25,04$ & .035 \\
Buah Naga Merah & $205,37 \pm 33,56$ & \\
\hline
\end{tabular}

Rata-rata pada kedua jenis sel antara kontrol negatif dengan kontrol positif memperlihatkan signifikansi .000 (P-value $<0,05)$ yang berarti perbedaan rata-rata bermakna secara statistik. Secara kuantitatif hasil memperlihatkan peningkatan jumlah sel spermatosit diikuti dengan menurunnya jumlah spermatid pada kelompok kontrol positif.

Induksi pakan tinggi lemak yang dilakukan memberikan perubahan degeneratif yang signifikan pada testis yang berasosiasi dengan spermatogenesis arrest pada tahapan spermatosit, maka terjadi peningkatan jumlah spermatosit namun diikuti penurunan jumlah spermatid. ${ }^{40} \mathrm{Hal}$ ini terjadi karena kegagalan mekanisme sinaps kromosom yang homolog pada saat profase 1 terutama karena dimediasi protein p63. ${ }^{4141}$ Stres oksidatif yang diinduksi oleh pakan tinggi lemak. ${ }^{4}$ akan merangsang DNA damage response dan menghasilkan protein p53 dan p63 yang akan berikatan dengan DNA binding sites yang menginduksi arrest pada siklus sel.$^{8,42}$

Jumlah spermatid yang menurun berhubungan dengan tingginya kadar adipokin pro-inflamasi yang diinduksi pakan tinggi lemak. Adipokin ini akan mengeluarkan leptin, resistin, TNF, IL-6, dan sebagainya. Adipokin tersebut merangsang Reactive Oxygen Species (ROS) dan inducible nitric oxide synthase (iNOS). ${ }^{5}$ yang akan menekan ATM Kinase sehingga merangsang mekanisme apoptosis sel. $^{8}$

Signifikansi antar kelompok pada kedua jenis sel sebesar .000 (P-value < 0,05) dapat disimpulkan bahwa terdapat perbedaan rata-rata yang bermakna diantara kelompok perlakuan simvastatin dan buah naga merah dengan kontrol positif.

Berdasarkan hasil perhitungan ratarata dapat dilihat pemberian intervensi simvastatin dapat mengembalikan jumlah spermatosit mendekati angka kontrol negatif dan terjadi memiliki diferensiasi yang lebih baik dibuktikan dengan peningkatan jumlah sel spermatid dibandingkan dengan kontrol positif. Simvastatin yang dalam penelitian ini telah berhasil menurunkan kadar kolesterol sebesar 28,00 dengan cara menghambat pembentukan kolesterol. ${ }^{34}$ sehingga tidak terjadi peningkatan stres oksidatif yang menyebabkan apoptosis.

Pemberian buah naga merah juga ternyata memperlihatkan diferensiasi sel yang lebih baik dilihat dari rata-rata spermatid yang meningkat jauh diatas kelompok kontrol, bahkan meningkatkan 
jumlah sel spermatosit secara signifikan. Buah naga yang kaya akan antioksidan dapat menekan stres oksidatif yang berlebihan, akibat kelainan metabolik yang diinduksi diet tinggi lemak. ${ }^{25}$

Dalam penelitian ini ekstrak buah naga merah dengan dosis $60 \mathrm{mg} /$ hari lebih efektif dalam menurunkan kadar kolesterol dibanding simvastatin bahkan memiliki potensi yang lebih kuat. Lalu, peneliti ingin membandingkan potensi pengaruhnya pada sel-sel spermatogenesis. Menurut analisis statistik dengan membandingkan rata-rata kelompok perlakuan menggunakan simvastatin dengan buah naga merah selama satu siklus spermatogenesis, didapatkan sel spermatosit dan sel spermatid memiliki perbedaan rata-rata yang bermakna dengan signifikansi dibawah 0,05 (P-value < 0,05). Kesimpulannya, kemampuan ekstrak buah naga merah lebih baik daripada penggunaan simvastatin dalam memperbaiki diferensiasi sel dan meningkatkan jumlah sel spermatosit dan spermatid yang terganggu karena pemberian pakan tinggi lemak.

Tabel 7. Perbandingan rata-rata Sel Perlakuan Buah Naga Merah 52 hari dengan 104 hari

\begin{tabular}{lcc}
\hline \multicolumn{1}{c}{ Perlakuan } & Rata-rata Sel & Sig. \\
\hline Spermatosit & & \\
52 Hari & $112,63 \pm 9,45$ & .013 \\
104 Hari & $129,07 \pm 9,34$ & \\
\hline Spermatid & & \\
52 Hari & $205,37 \pm 33,56$ & .465 \\
104 Hari & $217,77 \pm 22,40$ & \\
\hline
\end{tabular}

Hasil Uji statistik T-test Independent pada kadar kolesterol pemberian ekstrak buah naga merah selama 104 hari didapatkan penurunan efektivitas dibandingkan dengan pemberian selama 52 hari. Pemberian ekstrak buah naga secara kronis memperbaiki diferensiasi dan meningkatkan jumlah sel spermatosit dan spermatid dengan signifikansi sel spermatosit dibawah .013 (P-Value < 0,05) yang menandakan perbedaan bermakna dibandingkan pemberian subkronis dan spermatid sebesar .469 (P-value > 0,05) yang menandakan tidak ada perbedaan ratarata yang bermakna namun memperlihatkan peningkatan sebesar 12,40 secara laboratoris.

Berdasarkan hal tersebut pengaruh pemberian ekstrak buah naga merah terhadap jumlah sel-sel spermatogenesis secara kronis atau dalam dua kali siklus spermatogenesis sama dengan pemberian selama satu siklus spermatogenesis dan tidak menyebabkan kematian pada tikus percobaan, hal ini didukung oleh penelitian sebelumnya yang menyatakan bahwa pemberian ekstrak buah naga merah secara akut dan subkronis relatif aman selama tidak melewati dosis letal $1000 \mathrm{mg} / \mathrm{hari}^{28}$

\section{KESIMPULAN}

Berdasarkan hasil, analisa, dan pembahasan penelitian pemberian ekstrak buah naga merah (Hylocereus polyrhizus) terhadap gambaran spermatogenesis testis tikus putih (Rattus norvegicus) galur wistar yang diinduksi pakan tinggi lemak didapatkan kesimpulan sebagai berikut :

a. Induksi pakan tinggi lemak menggunakan telur puyuh dengan dosis $10 \mathrm{ml} / \mathrm{kgBB}$ dapat meningkatkan kadar kolesterol secara signifikan sebesar .000 (PValue $<0,05)$ dengan perbedaan rata-rata $36,33 \mathrm{mg} / \mathrm{dl}$ dibandingkan dengan kontrol negatif.

b. Induksi pakan tinggi lemak berpengaruh terhadap proses spermatogenesis pada fase spermatosit dan spermatid dengan signifikansi sebesar .000 (P-Value < 0,05). Jumlah spermatosit meningkat dengan perbedaan ratarata sebesar 87,60 diikuti dengan penurunan jumlah spermatid sebesar 110,57 dibandingkan dengan kontrol negatif.

c. Pemberian ekstrak buah naga merah (Hylocereus memperbaiki polyrhizus) proses 
spermatogenesis secara signifikan .000 (P-Value < 0,05) dibandingkan dengan kontrol positif. Ekstrak buah naga menurunkan rata-rata spermatosit sebesar 44,83 dan meningkatkan rata-rata spermatid sebesar 157,33.

d. Buah naga merah dengan dosis 60mg/hari dibandingkan dengan pemberian simvastatin dengan dosis 0,75mg/hari memperlihatkan pengaruh yang signifikan secara statistik dengan signifikansi dibawah 0,05 (P-value $<0,05)$ dalam memperbaiki sel spermatosit dan sel spermatid dengan perbedaan rata-rata secara berturut-turut sebesar 45,90 dan 39,53. Maka, buah naga merah memiliki efektivitas lebih baik dibandingkan dengan simvastatin dalam meningkatkan jumlah sel spermatogenesis.

e. Pemberian ekstrak buah naga merah selama dua kali siklus spermatogenesis memperlihatkan efek yang setara dengan pemberian selama satu siklus spermatogenesis dan tidak menyebabkan kematian pada tikus percobaan. Terjadi peningkatkan jumlah sel-sel spermatogenesis secara bermakna dengan signifikansi .013 (P-Value < $0,05)$ pada sel spermatosit dan meningkatkan rata-rata spermatid sebesar 12,40 secara laboratoris namun peningkatan rata-rata sel spermatid tidak bermakna secara statistik dibandingkan perlakuan selama satu siklus spermatogenesis.

\section{DAFTAR PUSTAKA}

1. Opie, L. H. Lifestyle and diet. Cardiovasc. J. Afr. 25, 298-301 (2014).

2. Moda Arsana Rulli Rosandi Asman Manaf AAG Budhiarta Hikmat Permana, P. \& Sucipta Dharma Lindarto Soebagijo Adi Bowo Pramono Dante Saksono Harbuwono Alwi Shahab Sugiarto Jazil Karimi Luthfan Budi Purnomo Agus Yuwono Tony Suhartono, K. W. Panduan Pengelolaan Dislipidemia di Indonesia-2015 Penulis Penerbit PB. PERKENI.

3. Harika, R. K., Eilander, A., Alssema, M., Osendarp, S. J. M. \& Zock, P. L. Intake of fatty acids in general populations worldwide does not meet dietary recommendations to prevent coronary heart disease: A systematic review of data from 40 countries. Ann. Nutr. Metab. 63, 229-238 (2013).

4. Balitbangkes. Riset Kesehatan Dasar 2013. 2013

5. Ouchi, N., Parker, J. L., Lugus, J. J. \& Walsh, K. Adipokines in inflammation and metabolic disease. Nat. Rev. Immunol. 11, 85-97 (2011).

6. Agarwal, A., Virk, G., Ong, C. \& du Plessis, S. S. Effect of Oxidative Stress on Male Reproduction. World J. Mens. Health 32, 1 (2014).

7. Aitken, R. J. \& Roman, S. D. Antioxidant systems and oxidative stress in the testes. Oxidative medicine and cellular longevity $\mathbf{1}$, 15-24 (2008).

8. Bagheri, M., Nair, R. R., Singh, K. K. \& Saini, D. K. ATM-ROS-iNOS axis regulates nitric oxide mediated cellular senescence. Biochim. Biophys. Acta - Mol. Cell Res. 1864, 177-190 (2017).

9. Jain GC. Hyper-Lipidemia and Male Fertility: A Critical Review of Literature. (2015). doi:10.4172/21670250.1000141

10. Anas, E. \& Asterina, A. EFEK 
PEMBERIAN JUST TOMAT (LYCOPERSICUM PYRIPORME) TERHADAP

SPERMATOGENESIS PADA TIKUS PUTIH (RATTUS NORVERGICUS) JANTAN DEWASA

HYPERKHOLESTROLEMIA. Maj. Kedokt. Andalas 35, 27 (2011).

11. Musfiroh, M. \& Gustari, S. PENGARUH PEMBERIAN MINYAK JINTAN HITAM (Nigella sativa L.) TERHADAP PENINGKATAN

SPERMATOGENESIS TIKUS WISTAR YANG TERPAPAR ASAP ROKOK. J. Kedokt. Hewan Indones. J. Vet. Sci. 9, (2015).

12. Erwinanto, A. S. \& Kasiman, J. Nugroho Eko Putranto, Pradana Tedjasukmana, R. S. S. R. S. PEDOMAN TATALAKSANA DISLIPIDEMIA. (2013).

13. Banach, M. et al. Statin intolerance An attempt at a unified definition. Position paper from an International Lipid Expert Panel. Arch. Med. Sci. 11, 1-23 (2015).

14. Indriasari, I. (Universitas U. ABSTRAK EKSTRAK ETANOL BUAH NAGA MERAH (Hylocereus polyrhizus) MEMPERBAIKI PROFIL LIPID TIKUS (Rattus Norvegicus)WISTAR JANTAN DISLIPIDEMIA SAMA EFEKTIF DENGAN STATIN. Tesis. (Universitas Udayana, 2012).

15. Handayani, S. (Universitas N. Y. KANDUNGAN KIMIA BEBERAPA TANAMAN DAN KULIT BUAH BERWARNA SERTA MANFAATNYA BAGI KESEHATAN. Dr. Sri Handayani - PDF Download Gratis. (Universitas Negeri Yogyakarta, 2014).

16. Kristianto. Buku Berkebun Buah Naga - Penebar Swadaya. 2014

17. Widianingsih, M. AKTIVITAS ANTIOKSIDAN EKSTRAK METANOL BUAH NAGA MERAH
(Hylocereus polyrhizus (F.A.C Weber) Britton \& Rose) HASIL MASERASI DAN DIPEKATKAN DENGAN KERING ANGIN | Widianingsih | Jurnal Wiyata: Penelitian Sains dan Kesehatan. $J$. Wiyata 3, 146-150 (2016).

18. Mahattanatawee, K. et al. Total antioxidant activity and fiber content of select Florida-grown tropical fruits. J. Agric. Food Chem. 54, 7355-7363 (2006).

19. Prakoso, L. O., Yusmaini, H., Thadeus, M. S. \& Wiyono, S. Perbedaan efek ekstrak buah naga merah (Hylocereus polyrhizus) dan ekstrak buah naga putih (Hylocereus undatus) terhadap kadar kolesterol total tikus putih (Rattus norvegicus). (Fakultas Kedokteran Universitas Pembangunan Veteran Jakarta, 2017).

doi:10.25182/jgp.2017.12.3.195-202

20. Sharan. Ekstrak Etanol Buah Naga Merah (Hylocereus Polyrhizus) Memperbaiki Profil Lipid Tikus (Rattys Novergicus) Wistar Jantan Dislipidemia sama Efektif dengan Statin. Intisari Sains Medis 8, 102109 (2017).

21. Aziz, F. A. \& Noor, M. M. Ethanol extract of dragon fruit and its effects on sperm quality and histology of the testes in mice. 21, 126-130 (2010).

22. Creswell, J. . Research Design: Qualitative, Quantitative, and Mixed Methods Approaches. (USA: Sage Publications, Inc., 2013).

23. Sastroasmoro, $\mathbf{S}$ dan Ismael, $\mathbf{S}$. Dasar-dasar Metodologi Penelitian Klinis , Edisi 4. Sagung Seto, Jakarta (2011). Available at: https://www.researchgate.net/publica tion/325265072_Dasardasar_Metodologi_Penelitian_Klinis . (Accessed: 11th December 2019)

24. Hastono, S. P. (Universitas I. Analisis Data. (Universitas Indonesia, 2006).

25. Kim, H.-Y. Statistical notes for clinical researchers: post-hoc 
multiple comparisons . Restor. Dent. Endod. 40, 172 (2015).

26. Singh, N. U., Roy, A. \& Tripathi, A. K. Non Parametric Tests: Hands on SPSS. (2013).

27. Dahlan, M. S. Statistik Untuk Kedokteran Dan Kesehatan: Deskriptif, Bivariat, dan Multivariat Dilengkapi Aplikasi Menggunakan SPSS. $2017 \quad$ (Epidemiologi Indonesia).

28. Hor, S. Y. et al. Safety assessment of methanol extract of red dragon fruit (Hylocereus polyrhizus): Acute and subchronic toxicity studies. Regul. Toxicol. Pharmacol. 63, 106-114 (2012).

29. Bogor), A. (nstitut P. PENGARUH PEMBERIAN KITOSAN TERHADAP KADAR KOLESTEROL TOTAL TIKUS (Sprague-dawley) YANG DIBERI PAKAN TINGGI ASAM LEMAK TRANS AGUSTINA DEPARTEMEN GIZI MASYARAKAT FAKULTAS EKOLOGI MANUSIA INSTITUT PERTANIAN BOGOR BOGOR 2014. (Institut Pertanian Bogor, 2014).

30. Istianah, E. T. (Universitas M. S. PERBEDAAN KADAR ASAM URAT PADA PASIEN TIDAK PUASA DENGAN PASIEN PUASA 8, 10 DAN 12 JAM. (Universitas Muhammadiyah, Semarang, 2016).

31. Celik, I., Tuluce, Y. \& Isik, I. Evalution of toxicity of abcisic acid and gibberellic acid in rats: 50 days drinking water study. J. Enzyme Inhib. Med. Chem. 22, 219-226 (2007).

32. Parasuraman, S. Toxicological screening. J. Pharmacol. Pharmacother. 2, 74 (2011).

33. Kusuma, A. M., Asarina, Y., Rahmawati, Y. I. \& Susanti, S. Efek Ekstrak Bawang Dayak (Eleutherine palmifolia (L.)Merr) dan Ubi Ungu (Ipomoea batatas L) terhadap
Penurunan Kadar Kolesterol dan Trigliserida Darah pada Tikus Jantan. J. Kefarmasian Indones. 6, (2017).

34. Murray, R. K. et al. Haper's Illustrated Biochemistry 28th ed. (2009).

35. Shi, Y. et al. The Regulation of Alfalfa Saponin Extract on Key Genes Involved in Hepatic Cholesterol Metabolism in Hyperlipidemic Rats. PLoS One 9, e88282 (2014).

36. Elon, Y., J. P. Manfaat Jeruk Nipis (Citrus Aurantifolia) Dan Olahraga Untuk Menurunkan Kolesterol Total Klien Dewasa. J. Sk. Keperawatan 1, 148-155 (2015).

37. Haschek, W. M., Rousseaux, C. G. \& Wallig, M. A. Male Reproductive System. in Fundamentals of Toxicologic Pathology 553-597 (Elsevier, 2010). doi:10.1016/B9780-12-370469-6.00018-0

38. Reece, J.B., Urry, L.A., Cain, M.L., Wesserman, S.A., Minorscky, P.V., JAckson, R. B. Campbell Biology, 9 th Ed. (Pearson Education,Inc, 2011).

39. Cheah, Y. \& Yang, W. Functions of essential nutrition for high quality spermatogenesis. Adv. Biosci. Biotechnol. 02, 182-197 (2011).

40. Ashrafi, H. et al. The effect of quince leaf (Cydonia oblonga miller) decoction on testes in hypercholesterolemic rabbits: a pilot study. Afr. J. Tradit. Complement. Altern. Med. 10, 277-282 (2013).

41. Jan, S. Z. et al. Distinct prophase arrest mechanisms in human male meiosis. (The Company of Biologists Ltd, 2018). doi:10.1242/dev.160614

42. Dötsch, V., Bernassola, F., Coutandin, D., Candi, E. \& Melino, G. p63 and p73, the ancestors of p53. Cold Spring Harb. Perspect. Biol. 2, 1-14 (2010). 